\title{
Evaluating the Tourism-Led Economic Growth Hypothesis in a Developing Country: The Case Of Albania
}

\author{
Jonel Kristo ${ }^{1}$ \\ Economic Research Department \\ Center for Economic and Business Education, Tirana, Albania
}

\section{Doi:10.5901/mjss.2014.v5n8p39}

\begin{abstract}
This paper evaluates the impact of tourism on economic growth for Albania using an error correction mechanism approach. We compare fluctuations in the total economic contribution of the travel and tourism sector in the economy and the real effective exchange rate, with changes in real GDP growth rate. Using a cointegration method for the long run analysis and the error correction mechanism to assess the short run dynamics of the model, we conclude that a 5 percent increase in net earnings from travel and tourism in Albania accounts for more than 1.7 percent increase in real income. We also assess that in the event of a break in the long run equilibrium between tourism and economic growth, it would take 26.3 percent correction effort per quarter to reestablish the equilibrium relation to its determined level. This means that the time period needed to weather an economic shock in the tourism sector and get it back to its long run equilibrium is almost one year (or 11.4 months). Generally speaking, the results found in this study support the hypothesized conviction that tourism development supports higher GDP growth ratios.
\end{abstract}

Keywords: tourism, economic growth, cointegration, error correction mechanism, Albania

\section{Introduction}

The first tourism development strategy in Albania was drafted in 2002 by the Ministry of Tourism, recognizing the sector's role in the economic growth of the country. This development strategy was approved in 2003, spanned until 2012, and was later revisited with two important initiatives. On June 2006, the Ministry of Tourism launched the new Strategy and Action Plan for the Development of Natural and Environmental Tourism, which was later followed by the Albanian Parliament approving a dedicated law on tourism development on May 2007. So, the administrative and executive support for tourism development has been welcoming of the long term vision for tourism growth in Albania. Quantitatively speaking, travel and tourism have a relatively high weight on domestic income, reaching 6.6 percent of GDP and an absolute value of 799 million USD in 2009 (the total economic contribution of the travel and tourism supply chain, through direct and indirect effects, reaches 2.4 billion USD and 20.6 percent of GDP, as reported in the Tourism Satellite Account of the World Tourism Organization).

It is relatively easy to assess tourism potential in Albania just by looking at its natural resources. The country hosts many forms of tourism, in addition to the already saturating tourism market of sea and sand. Remote tourism, in fact, is becoming the focal point of public policy support in this sector, meeting one of Milne's (1992) prerequisites for tourism growth - that of ensuring policy orientation on the importance of developing tourism. From the consumers' and individuals' standpoint, King and McVey (1997) and Bonham and Mak (1996) propose additional prerequisites to tourism growth, such as residents' willingness to accept the fact that development may impact their lifestyles, that private and public sector organization should be eager to contribute to tourism infrastructure, and that the compilation of effective marketing strategies concerning localities is pivotal to growth. The effect that tourism earnings can have on economic growth and welfare make it worth the trouble of public policy to impose the necessary expansionary regulation that support tourism growth. However, there has been no quantitative analysis conducted thus far on Albanian tourism that could have lead us to conclude with affirmation that tourism positively affects economic growth. Consequently, the central thesis of this paper is to evaluate the economic effect of tourism in quantitative terms, and offer an empirically valid result on the long run equilibrium relation between these two variables.

Given the novelty nature of our research and the developing cycle of tourism in Albania, we take some time to survey the relevant literature on economic effects of tourism growth. We track the global experience on tourism growth

${ }^{1}$ This paper was presented at the conference New Economic Growth Model for Albania, held in Berat, Albania, on May 3rd, 2010. Disclaimer: The views in this paper are those of the author and do not necessarily reflect those of the Center for Economic and Business Education. 
and adapt relevant applications for Albania. This section follows next. We then move on to presenting our model specifications and the time series upon which we base our study. The methodologies used here are covered in conceptual detail in Appendix 3, which should work well as introductory readings on cointegration and error correction mechanisms. Next, we present our empirical findings, and conclude with some final remarks.

\section{Literature Review}

The literature on tourism growth and its economic effects is vast, and seems to be generally oriented in three main directions: (1) tourism effects on income, (2) revenues instability in terms of cyclicality and seasonality of the sector, and (3) environmental implications of tourism growth, including sustainable tourism. This paper contributes to the first direction.

For several countries, it is now affirmed that tourism development poses great potential for economic growth. For example, Milne $(1990,1991,1992)$ asserts that developing countries, which are relatively small, but at the same time have unexploited tourist potential, have the luxury and opportunity to turn tourism into the mainstay of the region's economy as well as one of its largest employment sectors. In poorer countries tourism might serve as a tool that provides financial incentives for preserving cultural, historical and natural resources or traditions that would otherwise go neglected or degraded (Waters 1996; Mings 1969). We can realistically state that tourism could be alternatively defined as a powerful means for spreading economic activity to peripheral, underdeveloped areas (Parnwell 1993), as is the case for southern- and northern-most points of Albania.

One challenge to local communities might be the increase in domestic prices and its consequential effect on personal welfare and disposable income (Hazari and $\mathrm{Ng}$ 1993). Regardless of this prospect, it is plausible to believe that those effects are more than likely to be offset by the positive effects on the country's overall welfare (Balaguer and M. Cantavella-Jorda 2002). Williams and Shaw (1991) also mention tourism contribution on the convergence process of income. Using evidence from European countries, they evaluate that tourism generates a net distribution of wealth from richer to poorer states. In a more recent contribution, Soukiazis and Proenca (2007) prove the same point on income convergence for Portugal, helping regions to approximate their levels of development. Other authors conduct similar analysis on the effect of tourism for Mauritius (Durbarry 2004), Greece (Dritsakis 2004), Taiwan (Kim et al 2006), and Turkey (Gunduz and Hatemi-J 2005).

Complementary studies have tried to identify a possible link between tourism revenues and GDP growth. Po and Huang (2008) have established that when revenues from tourism are below $4.05 \%$ of GDP or above $4.73 \%$ of GDP, there exists a significantly positive relationship between tourism growth and economic growth. ${ }^{2}$ They argue that relatively low ratios of the value added from the service industry to GDP help explain the lack of a significant relationship between tourism growth and economic growth outside the range given above. Similar research by Chi-Ok Oh (2005) was conducted for the Korean economy, and it was found that such relation did not hold. Now, to the extent that the Korean and Albanian economy are not similar, and that the Albanian net earnings from tourism border at $4.73 \%$ of $\mathrm{GDP}^{3}$, we retain our hypothesis that tourism positively affects economic growth.

\section{Methodology}

As in Dritsakis (2004), we hypothesize that sustainable tourism growth can be successfully channeled to fuel economic growth and development in terms of income generation. Our hypothesis is that net earnings from tourism could be considered as a means of credit for financing local entrepreneurial activities, which in turn has the potential to employ more people, use more resources, and contribute to economic growth in sectors beyond tourism.

Following the empirical process in Dritsakis (2004) for Greek tourism, the econometric analysis here makes use of cointegration and autoregression models to assess the long run effect of tourism on growth. This method is extensively used in the literature, although other authors have also used computable general equilibrium (CGE) models (Adams and Parmenter, 1995; Dwyer et al, 2000), panel data approaches like the dynamic generalized method of moments (EugenioMartin et al, 2004), as well as endogenous and neoclassical growth models based on the Cobb-Douglas production function (Lanza and Pigliaru, 2000; Brau et al, 2003; Proenca and Soukiazis, 2008).

Given that we are analyzing the long run equilibrium relationship, as well as assessing the short term dynamics of

\footnotetext{
2 However, when that same variable is above $4.05 \%$ and below $4.73 \%$, such relationship does not hold.

${ }^{3}$ Total direct and indirect net earnings from travel and tourism industry have averaged 15.31\% of GDP for the period 2001-2009, with 2009 being a positive outlier of $20.6 \%$, while direct travel and tourism net earnings have averaged $4.71 \%$ of GDP over the same time period.
} 
the model, the Johansen (1995) methodology for non-level variables and an error correction representation of a general vector autoregression is used. This methodology is determined after conducting a stationarity test of the time series in our sample. According to Johansen (1995), if the variables mentioned above share a common stochastic trend and their first differences are stationary, than they can be cointegrated. The stationarity tests developed by Dickey and Fuller (1979, 1981) and Phillips and Perron (1988) are used to evaluate the unit root of the series. ${ }^{4}$ Campbell and Perron (1991) suggest that for unit root tests to have reasonable power properties, care must be exercised with deterministic regressors. To serve this purpose, Perron (1988) suggested sequential testing of models starting from the most general model containing a constant and a trend, a more modest model with only a constant, or a model with neither component.

We conduct the suggested strategy for our unit root tests in level and in first differences $(I(0)$ and I(1)). Table 1 in Appendix 2 shows the different stationarity tests with the corresponding probabilities. The tests revealed what is expected and customary of economic time series, that all variables were non-stationary in level, but stationary at first differences (I(1) - integrated variables of first order). Since the modeled variables are integrated of same order, it is suitable to use the Johansen and Juselius $(1990)^{5}$ technique, an approach based on maximum likelihood inferences. This is represented in an error correction form to estimate a short-run dynamic relationship between cointegrated variables and their rate of adjustment to the long-run equilibrium. The vector error correction model (VECM), as presented by Johansen and Juselius (1990) and as adjusted for this paper, looks as follows:

$$
\Delta y_{t}=\mathrm{A}_{0}+\sum_{i=1}^{k-1} \Gamma_{i} \Delta y_{t-i}+\Pi y_{t-1}+\varepsilon_{t}
$$

Where:

- $\quad \Pi=\sum_{i=1}^{k} \mathrm{~A}_{i}-I$ represents the long run matrix, with / as an identity matrix

- $\Gamma$ represents the short term adjustment and is equal to $\sum_{j=1+1}^{k} A_{j}$

- the $\Delta$ symbol represents variables in first differences

- $y_{t}$ and $y_{t-1}$ are the logarithms of the variables

- $A_{0}$ is the intercept and $\varepsilon_{t}$ is the Gaussian error term

- $A_{i}$ is a vector of variable coefficients

The log linear relationship between the chosen variables (explained in the next section) is expressed in an econometric equation as follows, with $u_{t}$ being the error term capturing omitted variables effects.

$\log R G D P_{t}=\beta+\beta_{1} \log R T U_{t}+\beta_{2} \log R E E R_{t}+u_{t}$

A multivariate cointegration analysis requires the selection of an appropriate lag length for the given variables. For small samples of, say, 60 observations, Liew (2004) detected that Akaike's early contribution with the Final Prediction Error (Akaike 1969) and the subsequent Akaike Information Criterion (Akaike 1973) performed better in correctly estimating the true lag length of autoregressive processes. In Liew (2004) these results were compared with other criteria like the Hannan-Quinn Information Criterion (HQIC), the Schwarz Information Criterion (SIC), and the Bayesian Information Criterion (BIC), and it resulted that, given sample sizes above 120 observations, the HQIC outperformed both SIC and the BIC. No overfitting issues were identified. Given these results, as well as keeping in mind the traditional research path in previous literature, we use the Akaike Information Criterion (AIC), and add the Schwarz Bayesian Information Criterion (SBIC) as being closely related to the earlier in terms of maximum likelihood estimation. These criteria resulted in an optimal lag length of 2 quarters.

\section{Variables}

Much of the logic that goes in choosing the variables to use when assessing the economic effects of the tourism sector depends on the nature of the sector itself. Tourism could resemble a non-traded good, but is nonetheless a kind of export in the realm of international trade. As such, tourism brings in monetary resources (such as foreign exchange), which could be turned around and used to import necessary commodities or be invested locally to improve economic development of the host country.

Income-generating tourist activities include net earnings from abroad, which is to be expected given the

\footnotetext{
${ }^{4}$ An additional stationarity test is conducted using KPSS test (1992) to distinguish series that appear to be stationary, series that appear to have a unit root, and series for which the data (or the primary tests) are not sufficiently informative to be sure whether they are stationary or need to be differenced. This is the case for our LRTU variable. For further information please refer to Kwiatkowski et al, (1992).

${ }^{5}$ For more information on cointegration please refer to Johansen (1988, 1991, 1995a), Johansen and Juselius (1990, 1994), and for a timeline review of cointegration refer to Dolado, Gonzalo, and Marmol (1999).
} 
international nature of the sector. As Albania becomes increasingly opened to international trade through lower barriers and tariffs, foreign money has been gaining considerable weight in the economy. In fact, a greater share of commercial loans as reported by the Bank of Albania for the last three years were denominated in foreign currency ( $72 \%$ of total credit). The positive economic effects of net earnings from abroad have been evaluated by Carletto et al (2007) for the first half of the transition period in Albania, but only for those earnings associated with return migration. ${ }^{6}$ Other authors have included variables that determine the weight of tourism on economic growth in terms of competition and scale. For example, Bhagwati and Srinivasan (1979) and Krueger (1980) see international tourism as an activity that contributes to economic growth by enhancing efficiency through increased competition among firms and other international tourist destinations, while Helpman and Krugman (1985) assert that higher tourism earnings facilitate the utilization of economies of scale in local firms.

\subsection{The Dependent Variable}

Measuring economic growth of a country when assessing the effect on it of one specific sector can be a challenging process, because the definition of economic growth is ambiguous. Several approximating indicators of economic growth exist, including real GDP, real GNI, as well as several per capita indicators. Further more, recently, economic growth has been measured by such indicators that incorporate some considerations on sustainability and environmental degradation, in addition to the common economic and monetary considerations (the Genuine Progress Indicator and the Index for Sustainable Economic Welfare are two valid examples). Obviously, for an unbiased analysis and evaluation of economic growth, one would need to account for the net effect of gross economic production, resource depletion, military and war burdens, and so forth. However, such ideal measures have yet to gain ground in the literature, and other measures are limited in availability for Albania. Therefore, we use real gross domestic product (RGDP) as a proxy for economic growth. Real GDP data are available with the required time frequency by the Albanian Institute of Statistics.

\subsection{Explanatory Variables}

To proxy for tourism growth, several alternative variables seem to have been used in the literature: the number of inbound tourists over population, the number of beds in accommodating facilities, tourism receipts as a share of exports, tourism receipts as a share of GDP, and net receipts from tourism. The first two variables could be appropriate to use since they not only cover the intensity of tourists' net earnings, but - as is the case of the number of beds available - it also shows changes in accommodating infrastructure. However, the data for these two variables is partially available, shorter than the time period required, less frequent than is needed for our analysis, and unreliable (Mema, 2009). Also, the data for these two variables is available annually, and it is impossible to find an adequate quarterly distribution of weights to interpolate the data quarterly. Moving on, tourism receipts as a share of exports or GDP could be used, but to preserve analytical consistency in our analysis, since real GDP is used as the dependent variable, net earnings from travel and tourism (RTU) are used to account for tourism growth. The Tourism Satellite Account (TSA) of the World Tourism Organization is used as a data source in this case. ${ }^{7}$

Another variable is the real effective exchange rate (REER). The industry of travel and tourism, especially in Southeastern and Southern Europe, is very competitive because the geographical uniformity and similar natural capital has lead to homogenous tourism products. Thus, international demand for Albanian tourism depends on the incrementally higher (or lower) attractiveness of Albania as a preferred tourist destination. This logic requires the use of a competitiveness indicator of an international nature, and the real effective exchange rate is used here to serve this purpose, as was the case in Dritsakis (2004). REER is an exchange rate-based, price-competitiveness indicator that has the required time frequency and is maintained by the Research Department at the Bank of Albania. ${ }^{8}$

Finally, as found in Lim and McAleer (2000), a dummy variable should be introduced in the model to account for seasonal effects. Travel and tourism is a seasonal (and even cyclical) sector, therefore a seasonal dummy variable was initially included in the model. However, significance tests showed that the variable was not statistically significant. Also,

\footnotetext{
${ }^{6}$ The authors show that the likelihood of owning a household enterprise improves with higher net earnings from abroad (not including tourism explicitly). ${ }^{7}$ Country data from the Bank of Albania's Balance of Payments were initially used for the analysis here. The data covered annual business and private trips, while TSA data explicitly cover net earnings from travel and tourism in the economy. Also, when using travel data from Bank of Albania, the results showed no significant relation between this variable and real GDP growth.

${ }^{8}$ Balaguer and Cantavella-Jorda (2002) use a similar approach to measure Spain's external competitiveness, but they adjust it for unit labor cost; while Dritsakis (2004) approaches external competitiveness as we do in this paper. In this context, affordability is considered as the key factor that will affect the sector's competitiveness, meaning that if the Albanian tourism is cheaper (i.e. more price-competitive) it will become more attractive to tourists, and if more tourists participate than net earnings will grow subsequently.
} 
Johansen (1995) argues that since seasonality might affect the mean but not the trend of tourism or economic growth, it is viable to leave the seasonal dummy out. The variables are expressed as logarithms to estimate the log linear relation between them, as well as to capture the proliferating effect of time series.

\section{Data}

We utilize quarterly data for Albania's net earnings from travel and tourism from 1998 to 2009, excluding the first 5 years of the transition period as a period with stagnant tourism development. Tourism data are taken from the World Tourism Organization. Data on the real effective exchange rate are taken from the Research Department at Bank of Albania. Real GDP data are taken from the Albanian Statistics Institute.

\section{Estimation Results}

Through the methodology used we check whether there are any cointegrating relations between our variables. Establishing the number of cointegrating vectors and estimating their parameters helps us analyze any long run relationships. Two likelihood ratio tests for the cointegration rank of matrix $\Pi$ in equation (2) are used: a maximum eigenvalue test and a trace test. The trace value is given to test the null hypothesis of having $r$ cointegrating vectors against the alternative of $k$ cointegrating vectors, where $k$ is the number of endogenous variables for $r=1,0, \ldots, k-1$. In addition, the maximum eigenvalue statistic tests the null hypothesis of having $r$ cointegrating vectors against the alternative of at least $r+1$ cointegrating vectors. We have three endogenous variables so we will test for $r=0, r \leq 1$, and $r$ $\leq 2$. The results of both these tests are included in table 2 in Appendix 2, and show that there are two cointegrating vectors among the variables used in this analysis. In the case where we have two endogenous variables, we take one less cointegrating vector than there are variables. So the one cointegrating relationship in the long run taken into consideration is the following: $L R G D P=0.348^{\star} \mathrm{LRTU}+0.851^{*} \mathrm{LREER}$

In addition, it shows that net earnings from travel and tourism in Albania positively affect the country's economic growth over time. Further more, table 6 presents the results of the Granger causality test that establishes causation ${ }^{9}$ through the channels mentioned in the vector identified above. Results show that both net earnings from travel and tourism and the real effective exchange rate Granger-cause growth in real GDP at the 5 and 10 percent significance level. ${ }^{10}$ However, the opposite is not true, meaning that growth in real GDP and changes in the real effective exchange rate do not Granger-cause net earnings in travel and tourism. Based on Hamilton (1994), this result suggests that past values of economic activity (real GDP) and greater price competitiveness (REER) in the country do not have enough predictive ability (i.e. Granger-causation) to affect future values of net earnings in travel and tourism.

Table 3 in Appendix 2 shows the estimated cointegrating parameters for the three variables. As can be inferred by the coefficient in table 3, it is estimated that a 5 percent increase in net earnings from travel and tourism in Albania accounts for an almost 1.7 percent increase in real gross domestic product in the long run. On the other hand, the short run dynamics of the error correction mechanism imply that any short run shocks to the long run equilibrium between real GDP and net earnings from travel and tourism is estimated to be undone by 26.3 percent each quarter. This further means that it will require almost 3.8 quarters (or 11.4 months) to weather an equilibrium shock in the long run caused by variations in the foreign exchange rate or total travel and tourism revenue - a mild correction pace of real GDP in a transition economy.

To further materialize the explanatory influence of these channels, we run a variance decomposition exercise. First, we conduct variance decomposition of real GDP explained by fluctuations in net earnings from travel and tourism and REER. Next, we conduct variance decomposition of net earnings from travel and tourism explained by fluctuations in real GDP and REER. Results shown in table 4 reveal that after 4 quarters, net earnings from travel and tourism explain 27 percent of fluctuations in real GDP, increasing to 36 percent after 8 quarters. On the other hand, real GDP and REER jointly explain about 23 percent of the fluctuations in net earnings in travel and tourism after 4 quarters, leaving 78 percent of the fluctuations in tourism to be explained by tourism itself.

Furthermore, the positive sign on LREER in the cointegration analysis could be interpreted in a way that links currency depreciation with higher attractiveness of Albanian tourism products and services for foreigners, which in turn should positively affect real GDP. In this regard, price competitiveness is considered an important factor in tourism

\footnotetext{
${ }^{9}$ Causation in terms of predictive ability of past values of $X$ in forecasting current values of $Y$ (Hamilton, 1994)

${ }^{10}$ The null hypothesis in this test is that the explanatory variable $X$ does not Granger cause the dependent variable $Y$. The result in this part of the paper means that there is correlation between the current value of real GDP and the past values of tourism and REER.
} 
growth, although to sustain the logic above it is necessary to conduct a collinearity test between LRTU and LREER. Perfect collinearity was not evident in EViews. To test for milder collinearity we generated a simple correlation coefficient (equal to -0.7519 ) and ran a t-test in this regard. ${ }^{11}$ The t-value of -7.3932 fell outside the 95 percent confidence interval, limited in the two tails by a critical t-value of $+/-2.018$. This outcome allows us to reject the null hypothesis that $L R T U$ and LREER suffer from multicollinearity.

To assess the robustness of the above results we run several diagnostics checks that are appropriate for vector auto regressions. The first diagnostics assessment tests for model stability using unit circles. The autoregressive roots graph shows that all but one root falls within the circle, and all but two roots are less than one. There are a total of $k^{*} p$ roots, or 9 roots. These results allow us to label the model as relatively stable. The second measure tests the serial correlation of residuals with the null hypothesis being that residuals suffer no serial correlation at lag order $h$. The test results do not allow the rejection of the null hypothesis, and we thus conclude that there is no residual serial correlation present. Next, we conduct a Wald test for parameter restrictions for all variables, with the restriction being the null hypothesis that all coefficients are zero. The results show that the small probability allows us to reject the null hypothesis, and contend that coefficients are different from zero, and thus significant at the 5 percent significance level. Next, we conduct a VEC residual normality test, with the null hypothesis being that residuals are multivariate normal. The high probability value of the Jarque-Berra coefficient with a Cholesky orthogonalization shows that residuals are normally distributed. Finally, the results of the residual heteroskedasticity test show that the model suffers no heteroskedasticity. The results of the diagnostic tests mentioned above are included in the tables in Appendix 2, saving the sequence mentioned above.

\section{Conclusions}

Throughout this paper we tried to assess the validity of the tourism-led economic growth hypothesis for Albania, and the empirical results obtained show that such hypothesis is valid. Growth in real income was measured through the growth rate of real GDP, which was compared with fluctuations in net earnings from travel and tourism since 1998. We also recognized the international nature of the sector and concluded that it was necessary to include an indicator that could control for the level of international price competitiveness of tourism. To this extent, the Research Department at the Bank of Albania prepares and maintains the real effective exchange rate, which we use in this paper as a proxy of international price competitiveness.

These three variables were than analyzed through an autoregressive approach. Using a cointegration method for the long run analysis and an error correction mechanism to assess the short run dynamics of the model, we concluded that a 5 percent increase in total travel and tourism revenues in Albania accounts for almost 1.7 percent increase in real income, an elasticity of 5-to-1.7. This finding is comparable and in line with the results of Balaguer and Cantavella-Jorda (2002) and Dritsakis (2004) where an elasticity of 5-to-1.5 held for Spain and Greece, in respective studies. Durbarry (2004) found an even more intensive elasticity, 5-to-4, for the island of Mauritius.

The findings in this study could help in legitimating ongoing efforts by state agencies and private organizations to further invest in tourism development for economic growth and improved economic conditions such as endemic unemployment, which is highest in those regions with higher endowments of tourism development factors ${ }^{12}$.

\section{References}

Adams, Philip D \& Parmenter, Brian R, (1995). "An Applied General Equilibrium Analysis of the Economic Effects of Tourism in a Quite Small, Quite Open Economy," Applied Economics, Taylor and Francis Journals, Vol. 27(10), pages 985-94.

Akaike, H. (1969). "Fitting autoregressive models for prediction". Annals of the Institute of Statistical Mathematics, Vol 21, pp. $243-247$.

Akaike, H. (1973). "Information theory and an extension of the maximum likelihood Principle". 2nd International Symposium on Information Theory, B. N. Petrov and F. Csaki (eds.), Akademiai Kiado, Budapest, 267 - 281.

Balaguer, J. and Cantavella-Jorda' , M. (2002) Tourism as a long-run economic growth factor: the Spanish case, Applied Economics, 34, $877-84$.

Bhagwati, J., and Srinivasan, T. (1979), "Trade policy and development', in Dornbusch, R., and Frenkel, J., eds, International Economic Policy: Theory and Evidence, Johns Hopkins University Press, Baltimore, MD, pp 1-35

Bonham, C. and Mak, J., (1996), Private Versus Public Financing of State Destination Promotion, Journal of Travel Research, 35 (2), 3-10.

Brau, R., Lanza, A. and Pigliaru, F. (2003) How fast are the tourism countries growing? The cross country evidence, FEEM Working Paper No. 85:2003,

${ }^{11}$ EViews 5 does not have an explicit test to detect collinearity, therefore the following formulas were used in sequential order. The first formula finds the simple correlation coefficient, the second formula converts that into a $t$-value, and the third formula finds the critical t-value. Two degrees of freedom were used, with an alfa of 5 percent. =@cor(Irtu,Ireer)=(@cor(IItu,Ireer $\left.)^{*}\left((@ o b s(\text { Irtu })-2)^{\wedge} .5\right)\right) /\left(\left(1-@ \operatorname{cor}(\text { Irtu,Ireer })^{\wedge} 2\right)^{\wedge} .5\right)=@ q$ qtdist (.975, (@obs (Irtu)-2))

12 In 2009 alone, it was estimated that 5.3 percent of the working labor force in Albania was directly employed in the tourism industry, and 16.6 percent of the working labor force was, directly and indirectly, employed in the travel and tourism supply chain (Tourism Satellite Account for Albania). 
Available at: http://ssrn.com/abstract1/4453340, accessed 30 March, 2006.

Campbell, John Y. and Pierre Perron (1991). "Pitfalls and Opportunities: What Macroeconomists Should Know about Unit Roots," NBER Macroeconomics Annual, 141-201.

Carletto, Gero, Talip Kilic, Benjamin Davis, and Alberto Zezza. "Investing back home: return migration and business ownership in Albania." Policy Research 4366 (2007). Web. 3 Apr. 2010. <http://go.worldbank.org/GM4QM01CF0>

Dolado JJ, Gonzalo J, Marmol F., (1999). Cointegration. Department of Economics, Statistics and Econometrics, Universidad Carlos III de Madrid, Getafe (Madrid), Spain.

Dickey, D.A., and Fuller, W.A. (1979), 'Distribution of the estimators for autoregressive time series with a unit root', Journal of the American Statistical Association, Vol 74, pp 427-431.

Dickey, D.A., and Fuller, W.A. (1981), 'Likelihood ratio statistics for autoregressive time series with a unit root', Econometrica, Vol 49, pp 1057-1072.

Dritsakis, N. (2004), 'Tourism as a long-run economic growth factor: an empirical investigation for Greece', Tourism Economics, Vol 10, № 3, pp 305-316.

Durbarry, R. (2004), 'Tourism and economic growth: the case of Mauritius', Tourism Economics, Vol 10, No 3, pp 389-401.

Eugenio-Martin, J.L., Morales, N.M., and Scarpa, R. (2004), Tourism and Economic Growth in Latin American Countries: A Panel Data Approach, Fondazione Eni Enrico Mattei Working Paper Series, Nota di Lavoro 26.2004, Milan, Italy.

Gunduz, L. and Hatemi-J., A. (2005) Is the tourism-led growth hypothesis valid for Turkey?, Applied Economics Letters, 12, 499-504.

Hazari, B. and A. Ng, (2003), 'An analysis of tourist's consumption of non-traded goods and services on the welfare of the domestic consumers', International Review of Economics and Finance, page. 3-58.

Helpman, E and Krugman, P. (1985) Market structure and foreign trade (MIT Press, Cambridge).

Johansen, S. (1988), 'Statistical analysis of cointegrating vectors', Journal of Economic Dynamics and Control, Vol 12, pp 231-254

Johansen, S., and Juselius, K. (1990), 'Maximum likelihood estimation and inference on cointegration: with application to the demand for money', Oxford Bulletin of Economics and Statistics, Vol 52, pp 169-210

Johansen, Søren (1991). "Estimation and Hypothesis Testing of Cointegration Vectors in Gaussian Vector Autoregressive Models," Econometrica, 59, 1551-1580.

Johansen, Soren \& Juselius, Katarina, (1994). "Identification of the long-run and the short-run structure an application to the ISLM model," Journal of Econometrics, Elsevier, Vol 63(1), pages 7-36.

Johansen, S. (1995), 'Likelihood-based inference in cointegrated vector autoregressive models', Oxford University Press, Oxford.

Kim, H.J., Chen, M., and Jang, S.S. (2006),“Tourism expansion and economic development: the case of Taiwan', Tourism Management, Vol 27, pp 925933.

King, B., and McVey, M., (1997). Hotel Investment in the South Pacific, Travel and Tourism Analyst 5, 63-87.

Krueger, A. (1980) 'Trade Policy as an input to Development', American Economic Review, 70, 188-292.

Kwiatkowski, D., Phillips, P. C. B., Schmidt, P. and Shin, Y. (1992), "Testing the null hypothesis of stationarity against the alternative of a unit root: how sure are we that economic time series have a unit root?, Journal of Econometrics, 54, 159-78.

Lanza, A. and Pigliaru, F. (1999) "Why are Tourism Countries Small and Fast Growing", Working Paper CRENoS 199906, Centre for North South Economic Research, University of Cagliari and Sassari, Sardinia.

Liew, Venus Khim-Sen, (2004). "On Autoregressive Order Selection Criteria," Computational Economics 0404001, EconWPA.

Mema, Fatmir (2009). "Tourism Statistics in Albania". Paper presented at the international conference on "Tourism Challenges in Albania.". European University of Tirana, Albania. 2009.

Milne, S., (1990). The Impact of Tourism Development in Small Pacific Island States. New Zealand Journal of Geography 89, $16-20$.

Milne, S., (1991). Tourism Development in Papua New Guinea. Annals of Tourism Research. 19 (2),191-212.

Milne, S., (1992). Tourism and development in South Pacific Microstates. Annals of Tourism Research 19 (2), 191-212.

Mings, R., (1969). Tourism's Potential for Contributing to Economic Development in the Caribbean. Journal of Geography 68, $173-7$.

Oh, C. (2005), 'The contribution of tourism development to economic growth in the Korean economy', Tourism Management, Vol 26, No 1, pp 39-44.

Parnwell, M. J. G., (1993). Environmental Issues and Tourism in Thailand. In: M Hitchcock, M., King V. T. and Parnell, M. J. G.(Eds.), Tourism in South-East Asia. Routledge: London, 286-302.

Perron, Pierre, (1989). "The Great Crash, the Oil Price Shock, and the Unit Root Hypothesis," Econometrica, Vol 57(6), pp. $1361-1401$.

Phillips, P.C.B., and Perron, P. (1988), 'Testing for a unit root in time series regression', Biometrika, Vol 75, pp 335-346.

Po, Wan-Chen, and Huang, Bwo-Nung, (2008), 'Tourism Development and Economic Growth: a Nonlinear Approach', Physica A, Vol. 387, No. 22, pp. 5535-42.

Proença, S., and Soukiazis, E. (2005), Tourism as an Alternative Source of Regional Growth in Portugal, Discussion Paper No 34, Centro de Estudos da União Europeia, Faculdade de Economia da Universidade de Coimbra, Coimbra.

Waters, R. R., (1996). The American Tourist. Annals of the American Academy of Political and Social Sciences 368, 109-118.

Williams, A., and Shaw, G. (1991), Tourism and Economic Development: Western European Experiences, 2nd Edition, Belhaven Press, London.

\section{Appendix 1: Variables description and data sources}

RTU - Real net earnings from travel and tourism in the overall economy: this variable accounts for the net economic contribution of the travel and tourism supply chain, in both direct and indirect channels. This measure records activity of the traditional travel and tourism providers such as lodging and transportation, as well as tourism-related investment, and public spending. Data is taken from the World Travel and Tourism Council, under the Tourism Satellite Account methodology. The measure is denominated in US dollars. Time period: quarterly from 1998 to 2009.

REER - Real effective exchange rate: this variable is a weighted index of the dominant foreign currencies for those countries with which Albania trades more intensely. This rate is prepared by llir Vika, Head of Modeling Unit in the Research Department at the Bank of Albania. Time period: quarterly from 1998 to 2009.

RGDP - Real gross domestic product: this variable measures the real total value of all goods and services produced in Albania. It is made available by the Albanian Statistical Institute (INSTAT). The measure is denominated in US dollars for the purposes of this paper. Time period: quarterly from 1998 to 2009. 
Appendix 2: Tables

Table 1: Stationarity Tests

\begin{tabular}{||l||cc|cc||cc|}
\hline \hline & \multicolumn{2}{|c|}{$\begin{array}{c}\text { Augmented Dickey } \\
\text { Fuller Test }\end{array}$} & \multicolumn{2}{c|}{ Phillips-Perron Test } & \multicolumn{2}{|c|}{ KPSS Test } \\
\hline Variables & $\begin{array}{l}\text { Level } \\
\text { prob. }\end{array}$ & $\begin{array}{c}1^{\text {st }} \text { differences } \\
\text { prob. }\end{array}$ & $\begin{array}{c}\text { Level } \\
\text { prob. }\end{array}$ & $\begin{array}{c}1^{\text {st }} \text { differences } \\
\text { prob. }\end{array}$ & $\begin{array}{c}\text { Level } \\
\text { prob. }\end{array}$ & $\begin{array}{c}1^{\text {st }} \text { differences } \\
\text { prob. }\end{array}$ \\
LRGDP & 0.0899 & 0.0000 & 0.1295 & 0.0000 & - & - \\
LRTU & 0.0365 & 0.0000 & 0.3184 & 0.0001 & 0.8387 & 0.0119 \\
LREER & 0.5154 & 0.0001 & 0.5127 & 0.0001 & - & - \\
\hline \hline \multirow{7}{*}{ Null: Variable is nonstationary at $5 \%$} & & & & & \\
\hline
\end{tabular}

Table 2: Johansen Cointegration Test (with maximum eigenvalue and trace test)

Sample (adjusted): 1998Q4 2009Q4

Included observations: 41 after adjustments

Trend assumption: Linear deterministic trend

Series: LRGDP LRTU LREER

Lags interval (in first differences): 1 to 2

Unrestricted Cointegration Rank Test (Trace)

\begin{tabular}{|lclll|}
\hline \hline $\begin{array}{l}\text { Hypothesized } \\
\text { No. of CE(s) }\end{array}$ & Eigenvalue & $\begin{array}{l}\text { Trace } \\
\text { Statistic }\end{array}$ & $\begin{array}{l}0.05 \\
\text { Critical Value }\end{array}$ & Prob.* \\
\hline \hline None * & 0.582258 & 60.80787 & 29.79707 & 0.0000 \\
At most 1 * & 0.456740 & 25.01936 & 15.49471 & 0.0014 \\
At most 2 & $6.17 \mathrm{E}-05$ & 0.002530 & 3.841466 & 0.9575 \\
\hline \hline Trace test indicates 2 cointegrating eqn(s) at the 0.05 level \\
* denotes rejection of the hypothesis at the 0.05 level \\
**MacKinnon-Haug-Michelis (1999) p-values \\
Unrestricted Cointegration Rank Test (Maximum Eigenvalue) \\
\hline \hline Hypothesized & \multicolumn{5}{c}{ Max-Eigen } & 0.05 \\
No. of CE(s) & Eigenvalue & Statistic & Critical Value & Prob.* \\
\hline None * & 0.582258 & 35.78850 & 21.13162 \\
At most 1 * & 0.456740 & 25.01683 & 14.26460 & 0.0002 \\
At most 2 & $6.17 \mathrm{E}-05$ & 0.002530 & 3.841466 & 0.0007 \\
\hline
\end{tabular}

Max-eigenvalue test indicates 2 cointegrating eqn(s) at the 0.05 level

* denotes rejection of the hypothesis at the 0.05 level

**MacKinnon-Haug-Michelis (1999) p-values

Unrestricted Cointegrating Coefficients (normalized by $b^{\prime *} S 11 * b=1$ ):

\begin{tabular}{lll}
\hline \hline LRGDP & LRTU & LREER \\
22.86505 & -7.952828 & -19.47948 \\
33.39445 & -9.086650 & 12.55915 \\
-10.36303 & -0.203906 & -17.96911
\end{tabular}

$-10.36303 \quad-0.203906 \quad-17.96911$

Unrestricted Adjustment Coefficients (alpha):

\begin{tabular}{llll}
\hline D(LRGDP) & -0.011494 & 0.004954 & 0.000118
\end{tabular}

$\begin{array}{llll}\text { D(LRTU) } & 0.079863 & 0.181775 & 0.000501\end{array}$

$\begin{array}{llll}\mathrm{D}(\text { LREER }) & 0.014308 & -0.006312 & 9.97 \mathrm{E}-05\end{array}$

1 Cointegrating Equation(s): Log likelihood 203.9554

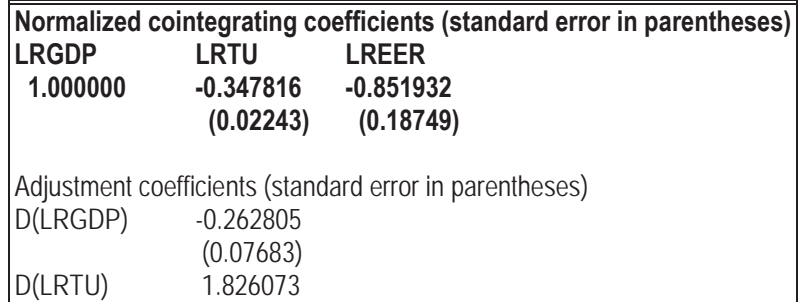




\begin{tabular}{|c|c|c|c|}
\hline D(LREER) & $\begin{array}{l}(1.13269) \\
0.327143 \\
(0.07913) \\
\end{array}$ & & \\
\hline 2 Cointegratin & Equation(s): & Log likelihood & 216.4638 \\
\hline \multicolumn{4}{|c|}{ Normalized cointegrating coefficients (standard error in parentheses) } \\
\hline LRGDP & LRTU & LREER & \\
\hline 1.000000 & 0.000000 & $\begin{array}{l}4.789256 \\
(0.48571)\end{array}$ & \\
\hline 0.000000 & 1.000000 & $\begin{array}{l}16.21890 \\
(1.57948)\end{array}$ & \\
\hline \multicolumn{4}{|c|}{ Adjustment coefficients (standard error in parentheses) } \\
\hline D(LRGDP) & $\begin{array}{r}-0.097374 \\
(0.13144)\end{array}$ & $\begin{array}{l}0.046394 \\
(0.03922)\end{array}$ & \\
\hline D(LRTU) & $\begin{array}{l}7.896350 \\
(1.54258)\end{array}$ & $\begin{array}{r}-2.286863 \\
(0.46025)\end{array}$ & \\
\hline D(LREER) & $\begin{array}{l}0.116348 \\
(0.13282) \\
\end{array}$ & $\begin{array}{r}-0.056428 \\
(0.03963) \\
\end{array}$ & \\
\hline
\end{tabular}

Table 3: Estimated Cointegration and ECM Parameters

\begin{tabular}{|c|c|c|c|}
\hline $\begin{array}{l}\text { Vector Error Corre } \\
\text { Sample (adjusted) } \\
\text { Included observat } \\
\text { Standard errors in } \\
\end{array}$ & $\begin{array}{l}\text { Q4 } \\
\text { djustments } \\
\text { in [] }\end{array}$ & & \\
\hline Cointegrating Eq: & CointEq1 & & \\
\hline LRGDP(-1) & 1.000000 & & \\
\hline LRTU(-1) & $\begin{array}{c}-0.347816 \\
(0.02243) \\
{[-15.5051]}\end{array}$ & & \\
\hline LREER(-1) & $\begin{array}{c}-0.851932 \\
(0.18749) \\
{[-4.54376]} \\
-6.132399 \\
\end{array}$ & & \\
\hline Error Correction: & D(LRGDP) & $\begin{array}{l}\mathrm{D}(\mathrm{LRTU}) \\
\end{array}$ & D(LREER) \\
\hline CointEq1 & $\begin{array}{c}-0.262805 \\
(0.07683) \\
{[-3.42060]}\end{array}$ & $\begin{array}{r}1.826073 \\
(1.13269) \\
{[1.61216]}\end{array}$ & $\begin{array}{r}0.327143 \\
(0.07913) \\
{[4.13406]}\end{array}$ \\
\hline $\mathrm{D}(\operatorname{LRGDP}(-1))$ & $\begin{array}{r}-0.679227 \\
(0.15557) \\
{[-4.36600]}\end{array}$ & $\begin{array}{r}-0.507618 \\
(2.29356) \\
{[-0.22132]}\end{array}$ & $\begin{array}{r}0.150780 \\
(0.16024) \\
{[0.94098]}\end{array}$ \\
\hline $\mathrm{D}(\operatorname{LRGDP}(-2))$ & $\begin{array}{r}-0.468090 \\
(0.15509) \\
{[-3.01813]}\end{array}$ & $\begin{array}{r}1.059156 \\
(2.28649) \\
{[0.46322]}\end{array}$ & $\begin{array}{r}0.287738 \\
(0.15974) \\
{[1.80126]}\end{array}$ \\
\hline D(LRTU(-1)) & $\begin{array}{r}-0.053383 \\
(0.02132) \\
{[-2.50385]}\end{array}$ & $\begin{array}{r}-0.378790 \\
(0.31432) \\
{[-1.20510]}\end{array}$ & $\begin{array}{r}0.069031 \\
(0.02196) \\
{[3.14354]}\end{array}$ \\
\hline D(LRTU(-2)) & $\begin{array}{r}-0.022328 \\
(0.01316) \\
{[-1.69632]}\end{array}$ & $\begin{array}{r}-0.359777 \\
(0.19405) \\
{[-1.85402]}\end{array}$ & $\begin{array}{r}0.035773 \\
(0.01356) \\
{[2.63869]}\end{array}$ \\
\hline $\mathrm{D}(\operatorname{LREER}(-1))$ & $\begin{array}{r}-0.250836 \\
(0.14697) \\
{[-1.70669]}\end{array}$ & $\begin{array}{c}0.359257 \\
(2.16677) \\
{[0.16580]}\end{array}$ & $\begin{array}{r}0.305739 \\
(0.15138) \\
{[2.01970]}\end{array}$ \\
\hline $\mathrm{D}(\mathrm{LREER}(-2))$ & $\begin{array}{r}-0.249726 \\
(0.14868) \\
{[-1.67963]}\end{array}$ & $\begin{array}{r}-0.687603 \\
(2.19194) \\
{[-0.31370]}\end{array}$ & $\begin{array}{r}0.143479 \\
(0.15314) \\
{[0.93693]}\end{array}$ \\
\hline C & $\begin{array}{r}0.040700 \\
(0.00573) \\
{[7.10242]}\end{array}$ & $\begin{array}{r}0.099390 \\
(0.08448) \\
{[1.17645]}\end{array}$ & $\begin{array}{r}-0.018317 \\
(0.00590) \\
{[-3.10346]}\end{array}$ \\
\hline R-squared & 0.515265 & 0.576180 & 0.410593 \\
\hline Adj. R-squared & 0.412442 & 0.486279 & 0.285567 \\
\hline
\end{tabular}




\begin{tabular}{|lrrr|} 
Sum sq. resids & 0.015276 & 3.320257 & 0.016206 \\
S.E. equation & 0.021515 & 0.317197 & 0.022161 \\
F-statistic & 5.011202 & 6.409046 & 3.284063 \\
Log likelihood & 103.6717 & -6.649116 & 102.4605 \\
Akaike AIC & -4.666912 & 0.714591 & -4.607830 \\
Schwarz SC & -4.332557 & 1.048947 & -4.273474 \\
Mean dependent & 0.018635 & 0.061959 & -0.006580 \\
S.D. dependent & 0.028069 & 0.442553 & 0.026218 \\
\hline \hline Determinant resid covariance (dof adj.) & $1.84 \mathrm{E}-08$ & \\
Determinant resid covariance & $9.59 \mathrm{E}-09$ & \\
Log likelihood & 203.9554 & \\
Akaike information criterion & -8.631969 & \\
Schwarz criterion & -7.503519 & \\
\hline
\end{tabular}

VAR Model - Substituted Coefficients:

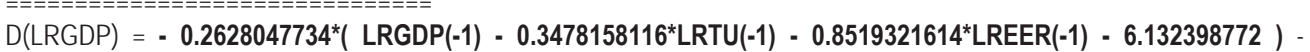
$0.6792271975 * D(L R G D P(-1))-0.4680897057 * D(L R G D P(-2))-0.0533830041 * D(L R T U(-1))-0.02232792564 * D(L R T U(-2))-$ $0.2508357721 * \mathrm{D}(\operatorname{LREER}(-1))-0.2497263521 * \mathrm{D}(\operatorname{LREER}(-2))+0.04070024798$

Table 4: Variance Decomposition

\begin{tabular}{|lllll|}
\hline \hline Variance Decomposition of LRGDP: & & & & \\
Period & S.E. & LRGDP & LRTU & LREER \\
\hline \hline 1 & 0.021515 & 100.0000 & 0.000000 & 0.000000 \\
2 & 0.024999 & 80.26160 & 18.71689 & 1.021514 \\
3 & 0.028745 & 72.43415 & 25.43222 & 2.133636 \\
4 & 0.035147 & 72.03374 & 26.53849 & 1.427771 \\
5 & 0.038698 & 66.62308 & 32.13153 & 1.245391 \\
6 & 0.042685 & 65.10653 & 33.79429 & 1.099183 \\
7 & 0.046512 & 64.26976 & 34.80061 & 0.929630 \\
8 & 0.049504 & 62.70685 & 36.43247 & 0.860675 \\
\hline \hline Variance Decomposition of LRTU: & & & & \\
Period & S.E. & LRGDP & LRTU & LREER \\
\hline \hline 1 & 0.317197 & 17.03379 & 80.40679 & 2.559418 \\
2 & 0.319354 & 17.48246 & 79.33962 & 3.177919 \\
3 & 0.328529 & 17.87646 & 76.10183 & 6.021707 \\
4 & 0.375355 & 14.62299 & 77.69947 & 7.677542 \\
5 & 0.383553 & 15.25922 & 76.07179 & 8.668985 \\
6 & 0.397101 & 15.97285 & 74.51942 & 9.507729 \\
7 & 0.418878 & 14.86357 & 74.70231 & 10.43412 \\
8 & 0.430445 & 15.38698 & 73.47410 & 11.13892 \\
\hline
\end{tabular}

Table 5: VEC Stability Condition Test

\begin{tabular}{|ll|}
\hline $\begin{array}{l}\text { Roots of Characteristic Polynomial } \\
\text { Endogenous variables: LRGDP LRTU LREER } \\
\text { Exogenous variables: } \\
\text { Lag specification: } 12\end{array}$ \\
\hline \hline Root & Modulus \\
\hline \hline 1.000000 & 1.000000 \\
1.000000 & 1.000000 \\
$-0.365507-0.633239 i$ & 0.731154 \\
$-0.365507+0.633239 i$ & 0.731154 \\
$-0.477692-0.521754 i$ & 0.707402 \\
$-0.477692+0.521754 i$ & 0.707402 \\
0.385126 & 0.385126 \\
$0.186175-0.330935 i$ & 0.379709 \\
$0.186175+0.330935 i$ & 0.379709 \\
\hline \hline VEC specification imposes 2 unit root(s). \\
\hline
\end{tabular}


Figure 4: Unit Root Stability Circle

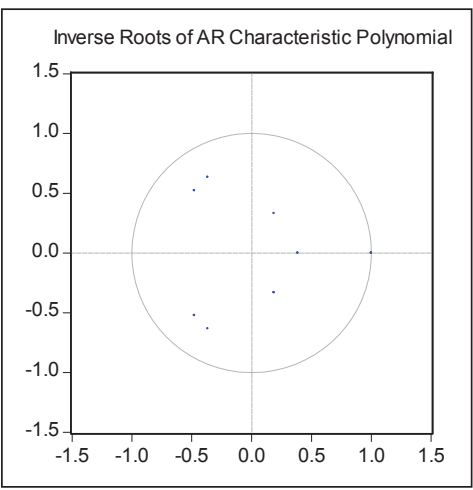

Table 6: VEC Residual Serial Correlation Test

\begin{tabular}{|c|c|c|}
\hline \multicolumn{3}{|c|}{$\begin{array}{l}\text { HO: no serial correlation at lag order h } \\
\text { Sample: 1998Q1 2009Q4 } \\
\text { Included observations: } 41\end{array}$} \\
\hline Lags & LM-Stat & Prob \\
\hline 1 & 14.26959 & 0.1131 \\
\hline 2 & 16.12940 & 0.0642 \\
\hline 3 & 6.577625 & 0.6810 \\
\hline 4 & 8.139171 & 0.5202 \\
\hline 5 & 10.50738 & 0.3110 \\
\hline 6 & 14.22402 & 0.1146 \\
\hline 7 & 4.215070 & 0.8967 \\
\hline 8 & 12.54530 & 0.1843 \\
\hline 9 & 9.718512 & 0.3738 \\
\hline 10 & 15.80915 & 0.0710 \\
\hline 11 & 4.302778 & 0.8904 \\
\hline 12 & 8.818901 & 0.4542 \\
\hline
\end{tabular}

Table 7: Granger Causality/Block Exogeneity Wald Test

\begin{tabular}{|llll|}
\hline $\begin{array}{l}\text { Sample: 1998Q1 2009Q4 } \\
\text { Included observations: 41 }\end{array}$ \\
\hline \hline Dependent variable: D(LRGDP) & & \\
\hline Excluded & Chi-sq & df & Prob. \\
\hline D(LRTU) & 6.459642 & 2 & 0.0396 \\
D(LREER) & 6.346224 & 2 & 0.0419 \\
\hline \hline All & 11.36318 & 4 & 0.0228 \\
\hline \hline Dependent variable: D(LRTU) & & \\
\hline Excluded & Chi-sq & df & Prob. \\
\hline D(LRGDP) & 0.468733 & 2 & 0.7911 \\
D(LREER) & 0.116948 & 2 & 0.9432 \\
\hline \hline All & 0.882554 & 4 & 0.9271 \\
\hline \hline Dependent variable: D(LREER) & & \\
\hline Excluded & Chi-sq & df & Prob. \\
\hline D(LRGDP) & 3.252796 & 2 & 0.1966 \\
D(LRTU) & 9.957152 & 2 & 0.0069 \\
\hline All & 13.03876 & 4 & 0.0111 \\
\hline
\end{tabular}


Table 8: Residuals Normality Tests

\begin{tabular}{|lllll|}
\hline $\begin{array}{l}\text { Orthogonalization: Cholesky (Lutkepohl) } \\
\text { H0: residuals are multivariate normal } \\
\text { Sample: 1998Q1 2009Q4 } \\
\text { Included observations: 41 }\end{array}$ & & & \\
\hline \hline Component & Skewness & Chi-sq & df & Prob. \\
\hline \hline 1 & 0.707174 & 3.417316 & 1 & 0.0645 \\
2 & 0.548506 & 2.055872 & 1 & 0.1516 \\
3 & 0.354531 & 0.858897 & 1 & 0.3540 \\
\hline \hline Joint & & 6.332085 & 3 & 0.0965 \\
\hline \hline Component & Kurtosis & Chi-sq & df & Prob. \\
\hline \hline 1 & 3.491109 & 0.412029 & 1 & 0.5209 \\
2 & 3.063786 & 0.006951 & 1 & 0.9336 \\
3 & 3.078561 & 0.010544 & 1 & 0.9182 \\
\hline \hline Joint & & 0.429523 & 3 & 0.9341 \\
\hline \hline Component & Jarque-Bera & df & Prob. & \\
\hline \hline 1 & 3.829345 & 2 & 0.1474 & \\
2 & 2.062822 & 2 & 0.3565 & \\
\hline 3 & 0.869441 & 2 & 0.6474 & \\
\hline \hline Joint & 6.761608 & 6 & 0.3435 & \\
\hline
\end{tabular}

Table 9: Residuals Heteroskedasticity

\begin{tabular}{|c|c|c|c|c|c|}
\hline $\begin{array}{l}\text { Sample: } 19 \\
\text { Included obs }\end{array}$ & $\begin{array}{l}\text { 2009Q4 } \\
\text { ations: } 41\end{array}$ & & & & \\
\hline Joint test: & & & & & \\
\hline Chi-sq & df & Prob. & & & \\
\hline 230.7724 & 210 & 0.1552 & & & \\
\hline Individual C & onents: & & & & \\
\hline Dependent & R-squared & $F(35,5)$ & Prob. & Chi-sq(35) & Prob. \\
\hline res1*res1 & 0.954238 & 2.978916 & 0.1122 & 39.12378 & 0.2899 \\
\hline res2*res2 & 0.992581 & 19.11352 & 0.0019 & 40.69583 & 0.2340 \\
\hline res3*res3 & 0.964164 & 3.843521 & 0.0683 & 39.53071 & 0.2747 \\
\hline res2*res1 & 0.985695 & 9.843954 & 0.0088 & 40.41351 & 0.2435 \\
\hline res3*res1 & 0.986363 & 10.33320 & 0.0079 & 40.44090 & 0.2425 \\
\hline res3*res2 & 0.995689 & 32.99319 & 0.0005 & 40.82324 & 0.2298 \\
\hline
\end{tabular}

Appendix 3: Cointegration and VECM explained

In this section we explain cointegration and the error correction mechanism in layman terms. It is intended for individuals with introductory knowledge of the methods used in this paper. We cover cointegration, the Johansen technique, and the vector error correction model. Oxford Reference Online, as well as the landmark publications, are used to derive the definitions mentioned here.

Cointegration is an econometric approach designed to predict whether two or more variables are linearly related. If two variables are linearly related, we would expect their values to move together over time. However, observations on these two variables may have a trend over time or may be drifting apart and are therefore not consistent with the modeling process. Nevertheless a linear regression of two variables may appear to fit the data very well and to give high t-statistics; therefore, additional tests should be conducted to determine that the cointegration is not in fact just spurious regression.

Cointegration is used when the relation between the time series is stationary, which is a condition discoverable by using several different stationarity tests such as the Augmented Dickey Fuller test and the KPSS test. A stationary time series is a series with a constant mean and variance over time and a covariance which depends on the time gap between the values rather than the period in time to which the observations relates. Two or more series of non-stationary random variables are cointegrated if there exists a stationary linear combination of these variables. A non-stationary series becomes stationary after differencing it $n$ times - and the series is than called integrated of order $\mathrm{n}$.

Cointegrated series drift together at roughly the same rate. More generally, if series $X$ and $Y$ are both integrated of order $n$, denoted I(n), and $Z=Y-\beta X$ is integrated of order $d$, denoted I(d) with $d<n$ for some constant $\beta$, then $X$ and $Y$ are cointegrated with the order of cointegration $(d-n)$; if $(d-n)$ is a fraction then $X$ and $Y$ are said to be fractionally cointegrated. Cointegration between two or 
more variables is expressed through a cointegrating vector.

Consider a vector $(X t)$ consisting of $n$ variables. These variables are said to be cointegrated if the following two conditions are met: (1) each of the variables is integrated of order I(d), and (2) there exists a cointegrating vector $z t=a 1 X t \sim I(d-n)$, where $n>0$. The term a1 is known as the cointegrating vector and the fact that the variables within Xt are cointegrated is denoted by Xt $\sim \mathrm{I}(\mathrm{d}, \mathrm{n})$. The cointegrating vector represents the long-run relationship between the variables in Xt and is therefore referred to as a long-run equilibrium relationship.

A conventional approach to using cointegration (following the development of a theoretical model) is to test each variable for the order of integration I(d). If the variables are all integrated of the same order (d), then test for the existence of a cointegrating vector. If this exists, formulate the error correction mechanism (covered below) representation of the model, estimate the coefficients, and perform nested significance tests to delete non-significant coefficients to derive a robust equation.

Error correction mechanisms are used when estimating cointegration relationships, which are also called cointegrating vectors, as mentioned above. An error correction mechanism is a dynamic model in which the change of the variable in the current time period is related to the distance between its value in the previous period and its value in the long-run equilibrium. This model is frequently used to estimate a short-run dynamic relationship between cointegrated variables and their rate of adjustment to the long-run equilibrium relationship. In the paper presented here we use a generalized form of the error correction mechanism called VECM - vector error correction mechanism. VECM is basically a system of equations that describe relations between multivariate non-stationary time series when there exists a cointegrating vector and the series are stationary of the same order (d).

To estimate a VECM one could use the Johansen's approach, which is based on the maximum likelihood estimation of a vector error correction model with several endogenous variables involving nonstationary, as well as stationary, variables (which is fine as long as their cointegrating vector is stationary). The maximum likelihood estimator is obtained by maximizing the likelihood function of a sample. The likelihood function indicates how likely a particular population is to produce an observed sample. This function likelihood produces some parameters, which are than used as estimators in the maximum likelihood estimation, whose main goal is to find the population that is more likely than any other to produce the observed data. The maximum likelihood estimators are known to be asymptotically efficient, which means that the level of precision provided by the estimator is close enough to the theoretical limit of precision, and as such, a sample estimator could be applied to the whole population (e.g. a sample mean of a normally distributed population is an efficient estimator of the population mean).

A final note is reserved for a light explanation of endogenous variables and the error terms. An endogenous variable is a variable whose value is determined by the equilibrium of a system, in contrast to an exogenous variable that is imposed on a system from outside. For example, the resource endowments of an economy are exogenous, whereas equilibrium prices are endogenous. In the context of econometrics, an endogenous variable is correlated with the error term in the regression.

In a regression, the difference between the dependent variable and the regression function is given by the size of the error term. It captures the combined effect of: (1) any deviation of the true functional form of the relationship between the dependent variable and the explanatory variables from the regression function; (2) any errors in measurement of the variables in the data; and (3) any variables that affect the dependent variable but are omitted from the regression function.

For details of the methods and significance tests, see:

D. A. Dickey and W. A. Fuller (1981), The likelihood ratio statistics for autoregressive time series with a unit root, Econometrica, 49: pp.1057-72;

R. F. Engle and C. W. Granger (1987), Cointegration and error correction: representation, estimation and testing, Econometrica: 50: pp.251-76;

W. A. Fuller (1976), Introduction to Statistical Time Series (Wiley \& Sons, New York); S. Johansen (1988), 'Statistical analysis of cointegrating vectors', Journal of Economic Dynamics and Control, 12: pp.231-54.

For definitional information on any of the concepts mentioned in this section, see:

A Dictionary of Economics. John Black, Nigar Hashimzade, and Gareth Myles. Oxford University Press, 2009. Oxford Reference Online. Oxford University Press. 